\title{
Research on the Teaching Evaluation System of Marketing Practice Based on Innovation and Entrepreneurship Orientation
}

\author{
Ya Wang \\ Dianchi College of Yunnan University \\ 13401247@qq.com
}

\begin{abstract}
Keywords: Marketing talents; Practical teaching; Innovation and entrepreneurship; Assessment system
\end{abstract}

\begin{abstract}
College marketing should attach importance to practical teaching, which is determined by the characteristics of higher education and the nature of marketing. However, in the course of teaching, the shortage of practical teaching resources, the teaching effect is not obvious and so on, which affect the quality of professional training, and can not reflect the advantages and characteristics of college education. Therefore, we should actively explore the existing problems in the practice teaching of marketing in Colleges and universities. Taking the marketing major of University as an example, this paper expounds the existing problems in the practice teaching assessment system of marketing specialty, and according to the goal of cultivating innovative marketing talents, comprehensively considering various factors and based on innovation and entrepreneurship. The construction of a practical marketing assessment system guided by marketing has been thoroughly studied.
\end{abstract}

\section{Introduction}

In recent years, the Ministry of Education has vigorously advocated innovation and entrepreneurship education in colleges and universities, cultivated college students' ability of innovation and entrepreneurship, encouraged college students to start their own businesses, and put forward the idea of starting employment through entrepreneurship. Therefore, improving the ability of college students to innovate and innovate and cultivating high-quality entrepreneurial talents has become one of the important goals of teaching in higher education institutions. Practical teaching is an important part of innovation and entrepreneurship education, which is very conducive to cultivating students' innovative spirit, practical ability and entrepreneurial ability. Compared with classroom teaching, practical teaching activities are characterized by comprehensive, procedural, open, multi-subjective, etc. The assessment of practical teaching is more complicated and more difficult to operate. In this context, strengthening practical teaching assessment and constructing a scientific, reasonable and practical assessment system is of great practical significance for guiding, standardizing and improving innovation and entrepreneurship education activities. This article takes the marketing profession as an example, starting from the practical problems of practical teaching assessment, combining the training objectives of innovation and entrepreneurship, exploring a diversified assessment system that meets the characteristics of this specialty, and providing new ideas for other professions to strengthen practical teaching and promote the cultivation of innovative and entrepreneurial talents.

\section{The Necessity of Marketing Professional Reform}

With the proposal of quality education, some people think that the essence of quality education is to cultivate comprehensive talents. But for marketing students' professional skills and professional qualities, comprehensive training is not suitable for their future development. And now, the teaching materials of marketing, even the teaching content and teaching methods can not keep up with the pace of social economic development, which leads to the disjointed demand of the students and enterprises in the marketing of the colleges and universities. 
For any profession in the society, professional ethics is an indispensable element of employment. Integrity, dedication and responsibility are three essential components of any job. Of course, marketing is no exception. In order to explain the marketing theory to the students, the teachers should impart the relevant professional ethics to the students so that they can realize the importance of professional ethics and make them be conscientious and conscientious in the future work. As a social person, we must learn to cooperate. As a instructor, it is not only to teach the theory of professional knowledge of marketing, but as a necessary ability for students to work in the future - team cooperation and instructors should also be taught to students.

At present, most students lack the sense of cooperation, self centered and difficult to find their proper roles in teamwork. In addition, as a qualified marketing staff, we should also have the ability to strain, insight and other related abilities, which are lack of due attention in the traditional marketing teaching process. Therefore, we should make appropriate reforms to the current situation of marketing teaching.

\section{The Main Problems in the Practical Teaching of Marketing Specialty in Colleges and Universities}

1. practice teaching assessment goals are not clear, not enough emphasis

A clear assessment goal is the key to ensuring the effectiveness of practical teaching assessment. However, at present, many colleges and universities' teaching management departments, teachers, and students have unclear assessment targets for marketing teaching practice. They do not pay enough attention to assessments. The assessment methods are simple and flow in form. They cannot truly understand the mastery of students' marketing skills. The results are difficult to reflect the students' true marketing ability, and the assessment and supervision of the practical process needs to be strengthened.

2. the lack of an effective way to cultivate students' practical innovation ability

Due to the influence of traditional concepts, the marketing teaching of some colleges still has the problem of "heavy knowledge and light ability", not to mention the cultivation of students' innovative ability. The professional ability of marketing depends to a large extent on the innovative ability of marketers. Many marketing methods have obvious effects when others use them, but their effects are greatly reduced when they copy them. The reason is mainly because we learn from others successful marketing experiences, not improve it. Although the impact of the marketing principle is the same, but because of product marketing, marketing personnel of different quality and other factors, the results of marketing will not be the same. Therefore, reform and innovation must be carried out for specific marketing methods.

3. the lack of scientific approach to the assessment of teaching practice

The most prominent problem in the marketing course teaching is that the practical skills training is not really implemented. Although various colleges and universities have carried out various practical teaching activities, the results are not satisfactory. The reason is that the author believes that it is mainly due to the lack of quality assessment methods for practical skills training. Most college graduation examination of the marketing program, still to adopt a uniform way closed book exam. Because this kind of assessment method can only examine the students' memory ability, it is difficult to test the students' actual combat skill level, so it is not conducive to training practical talents.

\section{The Cause of the Main Problems in the Practical Teaching of Marketing Specialty in Colleges and Universities}

There is a deviation targeting professional

At present, our country is in the period of economic transformation, and the demand for marketing talents is large, and the colleges and universities in our country lack the accurate positioning for the training of marketing professionals, which makes the training specifications of marketing talents 
disconnect with the needs of the society. Higher vocational marketing majors have difficulty in obtaining employment, and high-quality marketing personnel are in short supply.

\section{2. lack of talent training}

At present, the curriculum of college marketing majors is basically subject-centered, and there is still no separation from the discipline, system, and integrity of knowledge. Compared with the curriculum of ordinary colleges and universities, except for the lesson, the content Basically the same, and the theoretical curriculum is more than the practical curriculum, and the only practical curriculum lacks the high vocational characteristics.

3. teaching methods and methods behind

There are still many phenomena in the marketing teaching of most colleges and universities, such as "teachers' lectures, note taking by students, taking notes after exams, and forgetting after exams". Many schools' marketing teaching is still "on paper", that is, "marketing" in the classroom, "planning" on the blackboard. The application of modern educational technology is not enough, the construction of laboratory and the construction of practice base are lagging behind, and the combination of production, teaching and research is not enough.

4. difficult training base construction

The main reason why marketing professionals are difficult to establish a stable off-campus training base is the rejection of enterprises. In a market economy, competition among enterprises is increasing the intensity of the conservative core secrets and shedding workers are self-preservation instinct behavior of enterprises. Therefore, we cannot require companies to voluntarily assume the social responsibility of training modern marketing talents. We should give more understanding to the rejection of the company.

\section{The Construction of Marketing Practice Teaching Assessment System Under the Guidance of Innovation and Entrepreneurship}

Using a variety of assessment methods, a number of assessment subjects jointly complete the assessment of students' innovation and entrepreneurship ability, clearly refine the direction and content of practical teaching, and better guide students to participate in practical teaching activities, and improve the pertinence of students' learning practices. Efficiency, the most important thing is that the assessment results are more objective, comprehensive and effective.

1. the multi-layered performance goals

The goal of marketing practice teaching assessment under the guidance of entrepreneurship is to encourage students to actively participate in the practice of innovation and entrepreneurship in the process of practical teaching, and gradually have the experience, consciousness, thinking and ability of innovation and entrepreneurship. The target of assessment can be divided into five objectives as follows: (1) knowledge objectives, promoting students to master the basic knowledge needed for innovation and entrepreneurship; (2) ability objectives, strengthening the training and training of students' innovative and entrepreneurial ability; (3) process objectives, guiding students to participate actively, completing the practice of innovative entrepreneurship and summarizing practical experience teaching. Training; (4) methods objective, to cultivate students' creative thinking and to use scientific research methods to analyze and solve social problems; (5) emotional attitude and value goals. Strengthen and improve students' awareness, motivation and spirit of innovation and entrepreneurship. The objective of knowledge and ability is the basic goal, and it is an indispensable foundation for the practice of innovation and entrepreneurship; the goal and objective of the process are the key objectives. It is the correction of the traditional teaching, which emphasizes the result and the light process of the traditional teaching, emphasizes the commonness and neglects the personality. The means and ways of ability and emotional goal are of special importance in practical teaching. The goal of emotional attitude and values is the ultimate goal, the motive force and motivation to realize the goal of knowledge and ability. It is the highest pursuit of practice teaching to cultivate the students' consciousness of innovation and entrepreneurship.

2. assessment content and standards of multidimensional 
Around the goal of practice teaching assessment, the examination content and standard should reflect all aspects of the students' innovative and entrepreneurial practice, not only should we pay more attention to knowledge examination, but also pay attention to the comprehensive evaluation of ability and accomplishment, realize the multi-dimensional evaluation of students' practical performance and effectiveness, fully integrate practice teaching assessment objectives and innovation and entrepreneurship. Capacity components. The contents of the assessment are as follows: (1) innovative and entrepreneurial knowledge is used to examine the students' mastery of the necessary knowledge of marketing, company operation, enterprise management, policy and regulations and other innovative enterprises. (2) innovation and entrepreneurial ability to check the students' ability to master team cooperation, opportunity identification, contingency ability, management ability, risk bearing ability Factors such as innovation and entrepreneurial ability; (3) innovative and entrepreneurial practice process to examine students' creative and entrepreneurial practice participation, process performance and completion effect; (4) innovation and entrepreneurship methods to examine the students' scientific research methods and innovative thinking ability; (5) innovative entrepreneurial attitude examination of students' desire, motivation, intention and intention of innovation and Entrepreneurship The formation of knowledge, spirit and so on. The formulation of evaluation criteria for curriculum assessment should be combined with the characteristics of the curriculum, adhere to the principles of scientific and reasonable, accurate and standard, establish different assessment indexes and weights for different assessment contents, and complete the final assessment by different assessment subjects with appropriate assessment methods.

3. diversification of assessment methods

The assessment method should be based on the training objectives and assessment contents of innovation and entrepreneurship, and should be closely combined with specific practice teaching modes and channels. The diversity, complexity and diversity of marketing practice teaching forms of innovative and entrepreneurial practice require that process assessment, open assessment, developmental assessment and social assessment should be adopted as much as possible in the assessment. The specific forms and methods of assessment and evaluation are as follows: (1) students can be used in the subject of assessment. Evaluation and mutual evaluation, teacher evaluation, social evaluation, interactive assessment and other ways; (2) there are process assessment and result assessment in the content of assessment; (3) there are qualitative and quantitative assessment in the assessment standards; (4) there are closed assessment in the form of assessment, such as oral examination, written examination, field operation and so on; Type examination, such as practice log, report, planning book, etc. In practical application, various assessment methods should be combined effectively according to the contents and standards of the assessment, so that the evaluation of the course assessment is more comprehensive, fair and scientific.

\section{Conclusion}

Colleges and universities should correctly understand and face the problems existing in the current marketing professional teaching process, make use of the current situation of innovation and entrepreneurship, give full play to the characteristics and advantages of the marketing professional practice teaching links, combine the "production and learning", and encourage students. Participate in social practice, take high-quality innovative and entrepreneurial talents as the teaching goal, build a perfect marketing practice teaching system and the corresponding evaluation system to achieve the purpose of cultivating innovative and entrepreneurial talents.

\section{References}

[1]Tajeddini K. Effect of Market Orientation and Entrepreneurial Orientation on Innovation: Evidence from Auto Parts Manufacturing in Iran[J]. Journal of Management Research, 2011, 11(1):20-30. 
[2]Liu M Z, Feng J I, Zhou M H, et al. Research on Practice Teaching System of Marketing Based on" SPM" Mode__ A Case Study of Constructing Practice Teaching System of Marketing Discipline in China University of Mining and Technology[J]. Meitan Higher Education, 2013.

[3]Wei C. Teaching Model Innovation and Practice Research on Marketing Specialty based on CDIO in Higher Vocational Institutions[J]. Journal of Environmental Management College of China, 2012.

[4]Wang L. Research on Evaluation Index System Construction of Students' Innovation Ability Based on Marketing Practice Teaching[J]. Jiangsu Science \& Technology Information, 2016.

[5]Xian-Jiang L I. Mediating Effect Study on Marketing Innovation Between Entrepreneurial Orientation and Organizational Performance__Empirical Research Based on the Enterprises in Eight Cities of Mid-eastern China[J]. R \& D Management, 2012.

[6]Maatoofi A R, Tajeddini K. Effect of Market Orientation and Entrepreneurial Orientation on Innovation[J]. Journal of Management Research, 2013, 11(1):20-30.

[7]Zhang C. Approach to the Practice Teaching Reform of Internet Marketing Course for Independent Institutes in an Employment-Entrepreneurial Orientation[J]. Logistics Engineering \& Management, 2012.

[8]Liao J Y. Research on Practice Teaching System of Collaborative Innovation in Higher Vocational Marketing Major-Taking Zhejiang Yuying Vocational and Technical College as an Example[J]. Higher Vocational Education, 2015.

[9]Chui-Li H U, San-San L I. Research on the Practice System of Innovation and Entrepreneurship Based on Virtual Simulation[J]. Journal of Hubei Correspondence University, 2017.

[10]Xie R J. Research on the practice teaching system as the goal of innovation and entrepreneurship ability cultivation[J]. Laboratory Science, 2016.

[11]Wang Y T, Xiu-Jun L U, Zhang X L, et al. Research on Practical Teaching System of Tree Seeds and Seedling Nursery Based on Improving Students' Innovation and Entrepreneurship[J]. Heilongjiang Agricultural Sciences, 2017.

[12]Liu Y P, Zhao Z Y. Research on College Students' Entrepreneurship Education System Based on Demand Orientation[J]. Journal of Beijing University of Technology, 2017.

[13]Dapeng X U, Chen Y. Research on the Training Teaching Program Revision of Leisure Sports and Social Sports Specialty Majors Based onfrom the Employment Perspective of Employment:Taking the Capital Institute University of Physical Education and Sports as an Example[J]. Journal of Capital University of Physical Education \& Sports, 2017.

[14]Shan P, Pei J Y, School B, et al. Research on the Relationship between Entrepreneurial Orientation and Performance:The Mediating Role of Innovation Speed[J]. Journal of Hunan University, 2018. 